\title{
IMMIGRATION LAW AND RURAL POVERTY-THE PROBLEMS OF THE ILLEGAL ENTRANT
}

\begin{abstract}
SHELDON L. GREENE*
"They were making them take their shoes off in order to plant celery during the winter months when it was very cold. Anyone who did not want to would immediately be fired . . . . I told them to come with us into the union so that they would have someone to protect them. And he told me that La Casita Farms was paying $\$ 1.00$ an hour, that that was sufficient money to live with in Mexico . . . . And that is the reason for the workers that come here as strikebreakers because for them $\$ 1.00$ is sufficient to live in Mexico with." Statement of Baldemar Diaz, farmworker; Migrant Labor Subcommittee, Senate Committee on Labor and Public Welfare, Hearings Rio Grande City, Texas, June, 1967, 90th Cong., lst Sess, pt. II, 372.
\end{abstract}

I n 1966, the domestic farmworkers' wages were under one-half the average which prevailed in industrial employment, ${ }^{1}$ yet agricultural labor has been excluded from many. of the basic benefits designed to assuage the impact of poverty, such as unemployment compensation and coverage under the National Labor Relations Act. ${ }^{2}$ Efforts at unionization have failed recurrently because of the transiency of farm work, the mobility of farm laborers, and most important, the ready supply of replacements. The difficulties experienced by unions in the Southwest are in no small part due to the steady influx into the domestic labor market of inexpensive, non-resident Mexican labor. This article will consider deficiencies in the current immigration laws and in the enforcement of the law by

* General Counsel, California Rural Legal Assistance. LL.B. 1958, Western Reserve University.

' Recent Bureau of Census figures place the median family income of farmworkers at $\$ 2600$ in contrast to the overall United States median family income of $\$ 6900$. UNITED States Department of Agriculture, Agricultural Economic Report NUmber 121, DOMESTIC MIGRATORY FARMWORKERS 22 (1967).

$z$ "[A]ny individual employed as an agricultural laborer ..." is exempted from the act. National Labor Relations Act, 29 U.S.C. § 152(3) (1964). 
the Department of Justice and the Immigration and Naturalization Service contributing to the easy, and for the most part, illegal entry of the Mexican, non-resident alien into the labor market of the Southwestern United States.

\section{History}

The first "contract labor" law was enacted in the United States in $1885^{3}$ due to concern over the impact on domestic labor of high pressure recruitment of foreign workers by American industries. Importation of aliens under contract was prohibited except for temporary residents or persons with special skills not available in the United States. However, formal immigration and illegal entry by Mexicans in the Southwest has continued to disrupt efforts to obtain higher wages and job security..$^{4}$ With the onset of World War II, many domestic farmworkers were drawn to better paying city jobs, creating a labor shortage in agriculture. In 1942, Mexico and the United States established conditions of entry for Mexican agricultural workers, initiating the bracero program. ${ }^{5}$ Under this plan Mexican workers could not be employed to displace domestic workers at reduced wage scales but were to be paid at least a guaranteed minimum wage. Due to manifest racial discrimination, the Mexican government prohibited the exportation of braceros to Texas, in 1943..$^{6}$ However, to meet the needs of Texas farmers, the Immigration and Naturalization Service tacitly permitted a

\footnotetext{
${ }^{3}$ Act of February 26, 1885, ch. 164, 23 Stat. 332. A study conducted in 1890 disclosed wholesale evasion of the contract labor law prohibitions and led to further restriction. Act of March 3, 1891, ch. 551, 26 Stat. 1084.

- Between 1880 and 1930, above 1.5 million persons immigrated from Mexico to the United States. See generally 1967 Immigration and Naturalization Serv. ANN. Rep. 60.

3 Migration of Mexican Agricultural Workers Agreement with Mexico, Aug. 4, 1942, 56 Stat. 1759 (1942), E.A.S. No. 278. Revisions to the original agreement were made in Migration of Mexican Agricultural Workers Agreement with Mexico, April 26, 1943, 57 Stat. 1152 (1943), E.A.S. No. 351. Authority for the utilization of foreign labor was memorialized in Act of April 29, 1943, ch. 82, 57 Stat. 70. Between 1942 and 1947, 347,000 alien workers were employed in the United States under the auspices of the bracero program, of whom 219,500 were Mexican. See President's Commission on Migratory Labor, Migratory Labor in American Agriculture 38 (195I) [hereinafter cited Migratory LABOR (195I)].

- See Scruggs, Texas and the Bracero Program 1942-1947. Pac. Historical Rev.. August, 1963, at 254 [hereinafter cited as Scruggs, Bracero).
} 
wetback labor force to work on Texas farms with impunity. ' With the termination of the emergency labor program in 1947, the United States accorded legal status to the thousands of wetbacks who had illegally entered Texas. ${ }^{8}$

The bracero program was continued pursuant to an agreement between Mexico and the United States which allowed admission of aliens in accordance with the regulations of the Attorney General.9 However, Texas farmers balked at the minimum wage and the bond requirement insuring return of the worker to Mexico and for the most part chose instead to rely on illegal entrants..$^{10}$ In 1949 , Public Law $78^{11}$ formalized the previous agreement providing for recruitment, reception, transportation, and guarantees to workers. The law broadened the conditions protective of domestic labor, requiring reasonable efforts by growers to attract domestic workers prior to certification by the Labor Department of the need for foreign labor. Due to growing concern over the impact of the. bracero program on domestic labor, ${ }^{12}$ Congress refused to renew Public Law 78 in 1963. However, braceros continued to be introduced under the authority of 8 U.S.C. $\S 1101(\mathrm{a})(15)(\mathrm{H})(\mathrm{ii})$, which provided for the temporary admission of transient workers. ${ }^{13}$ Workers were admitted on the application of an

'See Scruggs, The U.S., Mexico, and the Wetback 1942-1947, Pac. Historical REV., May, 1961, at 150-52 [hereinafter cited as Scruggs, Wetback].

${ }^{8}$ Act of April 28, 1947, ch. 43, 61 Stat. 55. See generally Migratory Labor (1951), at 39.

- Migration of Mexican Agricultural Workers Agreement with Mexico. Feb. 20-21, 1948, 62 Stat. 3887 (1948), T.I.A.S. No. 1968.

1. See Seruggs, Bracero. at 261-63.

"Act of July 12, 1951, ch. 223, 65 Stat. 119.

12 Despite paper safeguards for domestic labor, President Kennedy, signing the final extension of Public Law 78 in 1961 commented: "The adverse effect of the Mexican farm labor program as it has operated in recent years on the wage and employment conditions of domestic farm workers is clear and cumulative in its impact. We cannot afford to disregard it. We do not condone it ...." Hearings on a Study of Population and Immlgration Problems Before a Subcomm. of the House Comm. on the Judiciary, 88th Cong., Ist Sess. 41 (1963). Between 1947 and 1963, the year Public Law 78 expired, 4.3 million braceros entered the United States to perform farm labor. U.S. DEP'T LABOR BULL. EMPLOyment Security, Farm Labor Serv., Fore1gn Workers AdMitied for TEMPORARY EMPLOYMENT IN UNITED StATES AGRICULTURE (Jan. 1963).

13 Temporary foreign labor is imported pursuant to 8 U.S.C. $\$ 1101(\mathrm{a})(15)(\mathrm{H})(1964)$ only when the prospective employer has satisfied criteria established by the Secretary of Labor in 20 C.F.R. $\S 602.10$ (1968) for recruitment of domestic farmworkers locally and interstate prior 
employer in the absence of certification by the Department of Labor that their importation would adversely affect domestic workers and on satisfaction by the grower of certain criteria consistent with previous international agreements. Ultimately, as a result of litigation reflecting dissatisfaction with the administration of its certification procedure, the Department of Labor agreed to disclose pending applications for foreign labor and to hold informal hearings prior to subsequent certifications. Due to the failure of California tomato growers to meet the preconditions required by the regulations, the Secretary of Labor announced that no braceros would be admitted in $1968 .^{14}$

\section{Illegal Entry}

Throughout the post-war bracero program, illegal entry from Mexico continued unabated. The earlier Texas accommodation of

to a determination of their non-availability. An employer makes a written request for certification describing his efforts to obtain United States workers. The local office of the Bureau of Employment Security must conduct an independent investigation prior to issuance of a certification. The Bureau must find that the employer has offered the following to domestic workers: housing, workmen's compensation insurance, a guarantee of at least $3 / 4$ of the work days of the total period during whieh the work contract and extensions are in effect at an established minimum hourly basic wage ( $\$ 1.68$ in California). Further, it must find that the employer has abided by state and loeal labor, health and housing laws, and that the admission of foreign workers will not result in the violation of policies of the U.S. Department of Labor governing the referral of workers to jobs involved in strikes or other labor disputes. An additional significant ground for refusal to certify is the notification to the Labor Department by the Immigration and Naturalization Service that the employer has hired illegal immigrants "unless the employer demonstrates that he did not know, had no reasonable grounds to suspect, or could not by reasonable inquiry have aseertained that the alien worker was not lawfully in the United States."

" In 1967, a suit was filed on behalf of domestic farmworkers against the Department of Labor, charging the failure of the Department to adhere to its own regulations prior to certifying the importation of $\mathbf{8 , 0 0 0}$ braceros for use in California agriculture. A temporary restraining order was obtained, but the case was dismissed within a few days due to the execution of a settlement agreement between the Department of Labor and California Rural Legal Assistance attorneys. Williams v. Wirtz, CCH Pov. L. Rep. 300.15 (N.D. Cal. 1967). The agreement laid down procedures for disclosure of pending applieations for foreign labor and hearings prior to subsequent certifications. Approximately 5,600 braceros were admitted that year.

In 1968 an investigation of the extent of recruitment and satisfaction of regulatory criteria by grower applicants for temporary labor undertaken by California Rural Legal Assistance indicated an almost total failure to effectively recruit available domestic labor prior to formal application for certification. The investigation also reflected multiple instances in which domestic workers were employed at lower hourly rates than were to be offered to temporary workers. See United States Dep't of Labor Release No. 8,971 (Sept. 24, 1968). 
illegal entrants, legitimizing the status of those subject to deportation, established a dependence on the wetback by South Texas industries and agriculture which attained the status of a de facto claim of right..$^{15}$ Complicity of the law enforcement officials with local farmers was again demonstrated in 1948 when 6,000 Mexican farmworkers who crossed the border without formality at El Paso, were paroled to Texas farmers in violation of the international agreement. ${ }^{16}$ The avoidance of the terms of international labor agreements strained relations with Mexico, which had in 1947 abrogated the labor treaty because of the continued use of wetback rather than bracero labor. Not only was the domestic Mexican labor supply disrupted but the avoidance of minimum wage and working condition standards by Texas employers represented an intolerable exploitation of the worker. ${ }^{17}$

In 1952, Congress took limited steps to interdict the flow of illegal entrants. Public Law $283^{18}$ made importation or harboring of illegal aliens a felony. As a concession to agricultural interests, however, providing employment and the normal practices incident to employment was excluded from punishment under the act. ${ }^{19}$ Two years later, the Justice Department commenced a nation-wide campaign to apprehend wetbacks and to transport them to the interior of Mexico. The sweep resulted in the apprehension of 331,000 aliens in San Antonio alone. More than 20,000 were collected in several northern cities..$^{20}$ The simple apprehension and return of wetbacks, however, has proven an ineffectual deterrent. Border Patrol officers indicate that three illegal entrants are undetected for every one apprehended..$^{21}$

lllegal entry is a crime. Initial entry is a misdemeanor and subsequent entries are felonies. ${ }^{22}$ Present enforcement efforts,

\footnotetext{
is See generally Migratory Labor (1951), at 73.

"See id. at 52.

${ }^{17}$ Average farm wages in 1950 ranged from a high of 88 cents per hour in California to a low of 54 cents in Texas. In contrast the Lower Rio Grande Valley, the area of highest wetback saturation, reported earnings of only 15 to 25 cents per hour. See id., at 78. See generally Scruggs, Wetback, at 152.

${ }^{18}$ Act of March 20, 1952, ch. 108, 66 Stat. 26.

19 Act of June 27, 1952, ch. 477, 66 Stat. 163.

* See 1954 Immigration and Naturalization Serv. AnN. Rep. at Table 29; 1955 immigration and Naturalization Serv. AnN. Rep. 15.

21 See generally 1967 Immigration and Naturalization Serv. ANN. Rep. 11.

28 U.S.C. §§ 1325-26 (1964).
} 
however, often involve a waiver of prosecution for first, second and third entries. ${ }^{23}$ In lieu of prosecution, illcgal entrants are flown or transported by train or bus to the interior of Mexico. ${ }^{24}$ Border Patrol officials attribute the failure to prosecute to the numbers involved, overburdened federal attorneys and disinterested courts. Moreover, the Immigration and Naturalization Service does not even process the initial offender as a deportee because to do so would unduly burden the limited agency hearing procedure.

A review of the development of the wetback problem and its impact on domestic workers leads to the conclusion that the wetback invasion must be controlled. Present efforts fall below acceptable levels of law enforcement. An excessive number of violations is no justification for the failure to exercise law enforcement responsibilities. If existing facilities for processing illegal entrants are inadequate they must be expanded or a way sought to provide for expedient formal disposition, unless wholesale voluntary departure occurs. Viewed in light of the past record of cooperation with agricultural interests, the Immigration and Naturalization Service's failure to subject wetbacks to formal deportation and prosecution is ambiguous at best. ${ }^{25}$ Yet Congress shares responsibility with the Service for the abundance of wetback labor. Additional funds could be made available to the $1 \mathrm{mmigration}$ and Naturalization Service to increase the Border Patrol and provide additional attorneys and inquiry officers to process the formal deportation of initial entrants and prosecute successive

Information obtained from the Western Region, Immigration and Naturalization Service, discloses that between July I, 1967 and June 30,1968, 149,169 prosecutions were waived.

${ }^{21}$ In 1967 over 17,000 aliens were flown to Mexican eities and 51,781 were transported by train to the interior of Mexico. 1967 Immigration AND Naturalization SERv. ANN. REP. 14.

${ }^{25}$ Apprehensions in relationship to size of the enforcement staff indicate that the Immigration and Naturalization Service diligently seeks to apprehend immigration law violators but is limited by the availability of officers. Although approximately $60 \%$ of the strength of the Border Patrol is situated in the Southwest, statistics obtained directly from the Immigration and Naturalization Service indicate that manpower limitations restrict the effectiveness of the enforcement staff.

Because of the volume of immigration violations, U.S. Attorneys generally limit prosecutions in the Southwest to aggravated cases involving economic exploitation, danger to life or patent falsification of documents. Sentences meted out by the judiciary in the Southwest for immigration law violations including smuggling are light. Suspended sentences are common and time actually served seldom exceeds several months. 
entrants. If Congress is willing to spend millions to transport wetbacks to Mexico it should be willing to finance sufficient staff to process them in accordance with the law.

A deterrent to effective curtailment of wetback infilitration for which the Immigration and Naturalization Service is free from blame, is the ease with which an uncredentialed illegal entrant can obtain a Social Security card and thereby demonstrate his right to reside in the United States. Another critical factor is the exemption of providing employment from 8 U.S.C. $\S 1324(a)(4),{ }^{26}$ which makes harboring, concealing or indirectly inducing the entry of an illegal entrant a felony. A farmer or labor contractor therefore need take no precaution in employing persons who by their clothing, speech and lack of documentation are undoubtedly illegal entrants. Since the farmer encounters no risk, he freely employs wetbacks, enhancing the inducement to cross the border.

If the flow of wetback labor is to be controlled, remedial legislation is imperative. The Social Security Act should be amended to provide that if the agency has reasonable cause to believe that a person is not lawfully in the country, the applicant can be required to present indicia of legal residence prior to the issuance of the Social Security card. Such indicia might be a driver's license and/or the alien registration card possessed by every alien entitled to work in the United States under the Immigration and Naturalization laws.

More important, the exemption from 8 U.S.C. $\S 1324$ accorded to employment of the wetback should be restricted to instances in which the employer has good cause to believe that the employee was lawfully in the United States. Presentation by the prospective employee of the alien registration receipt card and an American driver's license would be presumptive of good cause exonerating the

$\$ 8$ U.S.C. \& 1324 (1952) provides: "(a) [A]ny person, . . . who (3) willfully or knowingly conceals, harbors, or shields from detection, in any place, including any building or any means of transportation; or (4) willfully or knowingly encourages or induces, or attempts to encourage or induce, either directly or indirectly, the entry into the United States of -any alien, including an alien crewman, not duly admitted by an immigration officer or not lawfully entitled to enter or reside within the United States . . . shall be guilty of a felony, and upon conviction thereof shall be punished by a fine not exceeding $\$ 2,000$ or by imprisonment for a term not exceeding five years, or both, for each alien in respect to whom any violation of this subsection occurs: Provided, however, That for the purposes of this section, employment (including the usual and normal practices incident to employment) shall not be deemed to constitute harboring." 
employer from the threat of prosecution in the event that persons apprehended in his employ were in fact found to be illegal entrants. Exemplary prosecution of employers who chronically utilize wetback labor should cause employers generally to take precautions in ascertaining that prospective employees were properly in the United States. These additional measures should substantially limit the chance of employment and reduce the inducement to enter the United States.

\section{"The Man Who Came to Dinner"}

The 1mmigration and Naturalization Service reported in 1967 that 48,000 visitors "violated their status of admission." 25,000 visitors who were repatriated, most were found to have been illegally employed in the United States. ${ }^{28}$ The entry of Mexican aliens who visit the United States regularly is facilitated through the issuance of a "Mexican non-resident alien border crossing card.' 29 About 1,250,000 new cards are outstanding.0 The card may be presented at the border and entitles the Mexican citizen to remain in the United States for 72 hours in the area contiguous to the border. Violation of the conditions is difficult to discover, however, because no record is made of the date of entry and date of departure. Therefore the permit is literally a carte blanche enabling a visitor to travel freely and find seasonal employment with relative freedom from detection. Moreover, once issued, the card is valid indefinitely. ${ }^{31} \mathrm{~A}$ recent amendment to the Immigration and Naturalization Service regulations governing the admission of visitors restricts the usual 72-hour entrant to an area 25 miles from the border. Travel outside that zone in Texas, New Mexico, Arizona and California requires an additional document reflecting the date of entry and the place of admission..$^{32}$ Admittedly, an illegal

\footnotetext{
271967 Immigration and Naturalization Serv. ANN. Rep. 11.

¿ See United States Comm'n on Civil Rights, Staff Report, The Commuter on the U.S.-MEXICO BORDER 16 (1969).

$\Rightarrow 8$ C.F.R. $\$ 212.6$ (1968).

- See United States Comm'n on Civil Rights, Staff Report, The Commuter on the U.S.-MEXICO BORDER 16 (1969).

31 34 Fed. Reg. 129, amending 8 C.F.R. $\S 212.6$ (a) (1968), limited the area in which the Mexican citizen could remain to 150 miles from the border.

2 "(c) Validity, Notwithstanding any expiration date which may appear thereon, Forms I185 and I-186 are valid until revoked or voided." 8 C.F.R. $\$ 2$ I2.6(c) (1969).
} 
entrant might be apprehended in a roundup of wetbacks beyond the border area and be returned for having exceeded the geographical limit imposed on his visit; however, to date, no means exist to determine whether he has exceeded the 72-hour period. Curtailment of this abuse could be achieved by limiting visas or other documents of entry to one year and providing that all documents of entry must be stamped with dates of entry and departure for the purpose of ascertaining whether or not the term of stay has been violated.

\section{The Commuter}

Of the three classes of aliens which compete with domestic farmworkers, the status of the commuter alien is the most esoteric. The commuter is an alien who at one time was accorded the privilege of permanent residence and immigrant status yet continues to reside in a foreign country commuting daily or frequently to work in the United States. The exact number of such commuters working in the United States is not known, estimates varying considerably. ${ }^{34}$ Historically, the commuter developed from the existence of open borders between Canada and Mexico and the United States and the development of numerous contiguous border communities. With the establishment of national quotas in $1924,{ }^{35}$ the visa was established as a condition of entry. Commuter aliens were admitted without the necessity of a visa under the classification of temporary visitors for business. In 1927, however, the immigration authorities reexamined the issue and found that commuters could not_be classified as business_visitors but rather fell in the category of non-resident immigrants..$^{36}$

\footnotetext{
* See 34 Fed. Reg. 129 (1969), antending, 8 C.F.R. \$\$ 212.6(a), 235.1 \& 299.1 (1968).

It has been suggested that many illegal entrants cross the border with the 1-186 and then mail it back to Mexico so that in the event of apprehension the card is not confiscated and the holder can use it to re-enter. Fingerprints of applicants for the 1-186 are not now taken so that the Service is unable to match apprehended wetbacks with possessors of the 1-186 for the purposes of revocation. Accordingly, the actual revocations of the visitor's card reflect neither its actual abuses nor its relationship to illegal entry.

I It is estimated that some $90-100,000$ commuters work in Texas alone. Hearings Before the Subcomm. on Migrant Labor of the Senate Comm. on Labor and Public Welfare, 90th Cong.. Ist Sess., pt. 2, at 617 (1967).

${ }^{35}$ Act of May 26, 1924, ch. 190, 43 Stat. 153.

ss See generally Dep't of Labor and Dep't of Justice, Problems, Administrative Presentations III, 88th Cong., lst Sess. 162 (1963).
} 
The Supreme Court in Karnuth v. Albro ${ }^{37}$ found that commuters could not be permitted to enter under temporary business provisions but first had to obtain a visa. While the commuter issue could have been resolved at that point, had Immigration officials chosen to take the position that commuters were not immigrants unless they became residents, they instead promulgated a regulation which afforded commuters identification cards usable as entry documents. ${ }^{38}$

The classification of the commuter as an immigrant does little more than serve as a permit to work. Since the initiation of this policy, it has been established that in the event that a commuter ceases to be employed for a period of six months, his status will be presumed to have been abandoned. ${ }^{39}$ Moreover, the commuter alien is not eligible for naturalization, not having established an actual abode in the United States for himself and his family. ${ }^{40}$

An alien becomes a commuter by first obtaining an immigrant visa through the consulate in a foreign country. His eligibility to obtain an immigrant visa, which accords him the "privilege of residence in the United States, ${ }^{\prime 41}$ is dependent upon the definitions of "non-immigrant" enumerated in 8 U.S.C. $\S 1101(a)(15)$ since "immigrant" is defined as every alien except those falling in the subsequently defined categories of non-immigrant. In 1952 Congress added to the definitions of non-immigrant, category $\mathrm{H}$ (ii)-an alien having a residence in a foreign country which he has no intention of abandoning who comes to the United States temporarily to perform temporary labor. ${ }^{42}$ Under this definition it is obvious that commuter aliens making application for a visa would not be entitled to immigrant visas since many, particularly

\$2 279 U.S. 231 (1929).

2* 8 C.F.R. § $166.11-.15$ (1949).

\$ In re M.D.S., 8 I. \& N. Dec. 209 (1958). The Detroit Inspection Station which processes 5,000 commuters daily requires that each entering commuter furnish a letter from an employer at six-month intervals. A call-up system is employed to make sure that commuters regularly provide the certification of continuous employment. Testimony of Walter Sahli, District Director Immigration and Naturalization Serv., in Select Commission on Western Hemisphere Immigration Part IV. Impact of Commuter Aliens Along the Mexican and Canadian Borders 180, Mar. 8, 1968 (Detroit, Mich.).

so In re Correa, 79 F. Supp. 265 (W.D. Tex. 1948); In re Wright, 42 F. Supp. 306 (E.D. Mich. 1941); In re Barron, 26 F.2d 106 (E.D. Mich. 1928).

$\$ 8$ U.S.C. \& $1101(\mathrm{a})(20)(1964)$.

s2 Id. § $1101(\mathrm{a})(15)(\mathrm{H})(\mathrm{ii}):$ 
farmworkers, would fall precisely within the definition of nonimmigrant enumerated in subsection $\mathrm{H}$ (ii). However, assuming that the prospective commuter indicated his intention to become a resident and was not excluded under several categories of nonimmigrant, he would still be required to obtain a certification by the Secretary of Labor as a condition to entry.33

The certification, introduced by Congress in 1952, provided that no western hemisphere visa shall issue without the certification of the Secretary of Labor. The guaranty provided under 8 U.S.C. $\S 1182(\mathrm{a})(14)$ duplicated the certification required in the enactment of Public Law 78 as a condition of entry of seasonal braceros into the United States labor market. Aliens were to be excluded when the Secretary certified that sufficient domestic workers were available and employment of aliens would adversely affect wages and working conditions. ${ }^{44}$

The Secretary of Labor's certification responsibilities are implemented through 29 C.F.R. $\S \S 60.3-.6^{45}$ Three schedules are included therein which enumerate categories of employment relative to availability of domestic labor. For jobs listed therein Schedule $A^{16}$ is a certification of insufficiency of domestic workers and lack of an adverse effect on the domestic labor market. An applicant for entry whose employment is enumerated in Schedule A may obtain a visa from the consul without reference to the Department of 'Labor. In contrast, Schedule $B^{47}$ is an enumeration of jobs requiring minimal training and skills-categories deemed by the Bureau of Employment Security to be in sufficient supply. Applicants falling within any one category enumerated in Schedule B are ineligible for an immigrant's visa and such cannot be issued by the consular official. Jobs listed in Schedule $C^{48}$ include occupations of varying skills which might from time to time be in demand. Applicants for visas falling within the job categories listed in Schedule $C$ must submit a form to the Bureau of Employment Security which will make a timely determination of the availability of domestic

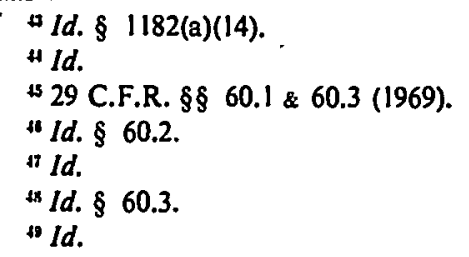


workers and the adverse effect on wages and working conditions reflected by examination of the local conditions at the time of application: The regulation $s^{49}$ provide that western hemisphere applicants ${ }^{50}$ whose categories of employment are not enumerated in any of the three schedules must request certification through the filing of a form describing the alien's qualifications as well as a form listing the specific prospective employment.

While the regulations are commendable in their concept, their practical application is another matter. The refusal to certify is predicated upon the availability to the Bureau of Employment Security of diverse data supplied through the cooperation of the Immigration and Naturalization Service. Without a high level of cooperation, the certification regulation is mere window dressing. Yet failures in inter-agency cooperation are not uncommon. ${ }^{51}$

Under proper enforcement of the 1952 law an applicant for a visa from Mexico should not obtain entrance if the Secretary of Labor made the certification of adverse effect on, and adequacy of, domestic labor. Assuming the Secretary declined to certify harm, an immigrant visa would be issued for no more than four months' duration ${ }^{52}$ For the four-month period that the visa was in force, it is clear that the immigrant had the right to enter and depart freely on presentation of the visa. Prior to expiration of the visa, the Immigrantion and Naturalization Service issued the immigrant a form 1-151, an Alien Registration Receipt Card commonly known as a greencard, which may be presented as a document of entry in lieu of the visa under the authority of 8 U.S.C. $\S 1181(\mathrm{~b})$. This section authorized the Attorney General in his discretion to readmit without immigrant visa or other documentation otherwise admissible aliens, lawfully admitted for permanent residence, who depart temporarily from the United States..$^{33}$

The Immigration and Naturalization Service, by a strained process of reasoning, construed the 1952 amendments to the

\footnotetext{
5o For a definition of western hemisphere applicants, see 8 U.S.C. \& 1101 (a)(27)(C) (1964).

si For an example of the breakdown in cooperation, see statement of Michael Peevey, Research Director, Cal. Labor Fed'n AFL-CIO, at Hearing Beforc the Select Commission on Western Hemisphere Immigration, pt. 11, 25 (Feb. 9, 1968, San Diego, Cal.). From July 1, 1966 to February 28, 1967, 2,509 workers were certified on a permanent basis in an area with more than $10 \%$ underemployment.

528 U.S.C. \$ 1201 (a) \& (c) (1964).

sId. $\S 1181(\mathrm{~b})$.
} 
Immigration and Naturalization Act as implicitly acceding to the perpetuation of the commuter status. Since the original 1924 Act provided that aliens "admitted as temporary visitors for pleasure" must not seek employment, the commuter must be classified as an "immigrant" and admitted temporarily for the purposes of employment. The mandate of 8 U.S.C. \& $1101(\mathrm{a})(15)(\mathrm{H})$, which classes as a non-immigrant a non-resident alien temporarily employed, was not viewed as applicable because the commuter was a fictitious resident having once been accorded immigrant status. It was further argued that even if entering temporarily, he was not performing temporary. services beeause he ostensibly worked on a regular basis. ${ }^{54}$

Analyzing the 1952 additions to the Act, the Justice Department concluded that it had the authority to continue to admit commuters under the language of section $1181(\mathrm{~b})$. A decision of the Board of Immigration Appeals concluded that the practice of considering commuters as permanent residents was not disturbed by the 1952 amendments. ${ }^{55}$ The Board reasoned that

... the phrase admission for permanent residence continues to refer to a status by which the alien is granted the privilege of residing in the United States permanently as an immigrant upon lawful admission. Thus a commuter who has been legally admitted as an immigrant is entitled to receive a border crossing identification card so long as he continues in that status. Similarly, a commuter is entitled to readmission under section $211(b)$ [ 8 U.S.C. $\S 1181(b)]$ as a returning resident while he maintains this status and complies with conditions controlling the use of border crossing cards. ${ }^{36}$

Thus, this rationale would appear to view the commuter working in the United States and living in Mexico as a United States resident, and his daily reentry in commuting to work as the readmission of a returning resident. The absurdity of this position is apparent.

The provisions inserted in the immigration laws for the protection of domestic labor were virtually nullified and commuters continued to enter until a 1960 strike at the Peyton Packing

"See immigration and Naturalization Serv., Opinion of Gen. Counsel No. 56336/101 (Jan. 9, 1953).

${ }^{3 s}$ In re H-O-, 51 \& N. Dec. 716 (Bd. of 1mmigration App. 1954).

M Id. at 718 (emphasis added, footnote omitted). 
Company in El Paso, Texas. Mexican commuter labor was employed by the plant to break the strike. The Secretary of Labor issued a certification, pursuant to 8 U.S.C. $\S 1182(\mathrm{a})(14)$, alleging that the entry of commuter aliens for the purpose of employment at the Peyton Packing Company would have an adverse effect on domestic labor. The Immigration Department, however, refused to honor the certification, determining that it was inapplicable to reentering commuters. As a result, suit was brought charging violation of the immigration laws. ${ }^{57}$ The court found that commuters had no status under the law as residents, and should be treated as non-residents. The waiver of former documentation found in 8 U.S.C. $\S 1181$ (b) authorizing aliens to enter upon presentation of the greencard was found to apply only to those persons who in fact had established permanent residence in the United States. Non-residents entering only to perform temporary labor were found to be non-immigrants within the definition of 8 U.S.C. $\S 110 l(a)(15)(H)$. The Immigration Service disagreed and the Justice Department restricted the rule to the particular fact situation. ${ }^{58}$

On the basis of the prior favorable decision, the Texas AFLCIO sought legal redress to require the Justice Department to exercise-administrative controls over all reentering commuters.50 The issue of the validity of commuter status, however, was circumvented by the court's determination that the Union and individual workers lacked standing to challenge enforcement of the immigration laws. ${ }^{60}$ The decision was apparently accepted by the Justice Department as a vindication of its position.

${ }^{57}$ Amalgamated Meatcutters v. Rogers, 186 F. Supp. 114 (D.D.C. 1960).

sx In re J-P-, 9 I. \& N. Dec. 591 (Bd. of Immigration App. 1962). "This is not to be considered as a general rule, but is to apply only to employees of the Peyton Packing Company . . . [as] determined by a Federal court decision ... ." Id. at 594.

33 Texas AFL-CIO v. Kennedy, 330 F.2d 217 (D.C. Cir. 1964).

${ }^{\infty}$ On the standing issue, the court relied, anong other cases, on Tennessee Elec. Power Co. v. T.V.A., 306 U.S. 118 (1939) (rejecting an attack by private power companies against the emerging T.V.A.) in stating that, absent a congressional grant of standing, "mere economic competition made possible by governmental action (even if allegedly illegal) does not give standing to sue in the courts to restrain such action." 330 F.2d at 219. However, the Tennessee Valley case had previously been impliedly overruled and discredited by the Supreme Court in F.C.C. v. Sanders Bros. Radio Station, 309 U.S. 470 (1940), in which a competing radio station was found to have standing to challenge a decision of the F.C.C. to permit the construction of an additional station. 
However, the defeat of organized labor by the Justice Department in the Texas AFL-ClO case was short-lived. In a hearing before the House Committee on the Judiciary, the General Counsel of the Immigration and Naturalization Service was asked how an alien commuter who had not established a residence in the United States could qualify under section $1101(a)(27)$ which defines a non-quota immigrant as one "returning from a temporary trip abroad." The Service fell back on the waiver of formal documentation of 8 U.S.C. $\S 1181(b)$ and argued that this section. allowed commuter status since it referred not to one returning from a visit but rather to a person who has departed from the United States. ${ }^{61}$ Congress' reaction was to precisely delete from 8 U.S.C. $\S 1181$ (b) the language relied upon by the Service to support the informal admission of commuter aliens. The qualifying language in the 1952 version, "aliens lawfully admitted for permanent residence who depart from the United States temporarily," was stricken. Inserted in its place was "returning resident immigrants, defined in section $1101(\mathrm{a})(27)(B)$ of this title, who are otherwise admissible . . . '62 Section $110 \mathrm{I}(\mathrm{a})(27)(\mathrm{B})$ relates to an alien who has becn previously admitted for permanent residence and who is returning from a temporary visit abroad. The commuter alien is not returning from a temporary visit abroad and therefore is not within that definition. It is likewise clear that the commuter is not a "returning resident immigrant" 63 either. Therefore, by its amendment Congress unequivocally excluded the commuter from the informal entry provisions found in section $1181(b)$.

Since commuters were deprived of the benefit of section $1181(\mathrm{~b})$, they were required to comply with section 1181 (a), which required as a precondition to entry a valid, unexpired immigrant visa. ${ }^{64}$ Therefore under the law commuters were required every four months, the maximum term of an immigrant visa, to return to the consulate and obtain a new visa. ${ }^{65}$ As western hemisphere applicants they

"See Hearings on a Siudy of Population and Inimigration Problenis Before a Subcomm. of the House Comm. on the Judiciary. 88th Cong., Ist Sess., at 163-69 (1963).

228 U.S.C. \& 1181 (b) (1964), as amended. (Supp. III, 1968).

- See text following note 56 supra.

of 8 U.S.C. \& 1181 (a) (1964) reads in part: "No immigrant shall be admitted into the United States unless at the time of application for admission he (1) has a valid unexpired immigrant visa ...."

"Id. \&. 1201 (a) \& (c). 
were again required to satisfy the certification requirements. ${ }^{66}$ This latter section was strengthened by Congress in 1965. Under the new version an affirmative certification by the Secretary of Labor that the domestic labor supply was inadequate and the entry of the alien would not adversely affect domestic wages and working conditions, had to be obtained as a condition to issuance of the visa.$^{67}$ Under the previous version of the law the applicant could enter unless the Secretary of Labor made a prohibitory certification.

The Justice Department treatment of the 1965 amendments was simply to ignore them. In an unprecedented example of administrative solecism, the Justice Department anachronistically found that the commuter status was no longer predicated on the maintenance of a "permanent and stable job" but rather accrued to persons who entered occasionally as temporary labor ${ }^{68}$ In doing so the Department ignored or was unaware of 8 U.S.C. $\S 110 \mathrm{i}(\mathrm{a})(15)(\mathrm{H})$ which specifically classed non-resident aliens who come to the United States temporarily to do temporary labor as ngn-immigrants. The Immigration and Naturalization Service argument in opposition to this change was characterized as "based upon unsupported references to the danger to American labor." 69 The Board of Immigration Appeals asserted in response ". . . that the applicant whose status as a commuter was recognized for many years has not lost his privilege ...."70 The Board failed to discuss or take into consideration the critical impact of the 1965 amendments to the Immigration and Naturalization laws." The

"See notes 44-50 supra and accompanying text.

$" 8$ U.S.C. \& 1182(a)(14) (1964), as amended, (Supp. 111, 1968): “Aliens seeking to enter the United States, for the purpose of performing skilled or unskilled labor, unless the Secretary of Labor has determined and certified to the Secretary of State and to the Attorney General that (A) there are not sufficient workers in the United States who are able, willing, qualified, and available at the time of application for a visa and admission to the United States and at the place to which the alien is destined to perform such skilled or unskilled labor, and (B) the employment of such aliens will not adversely affect the wages and working conditions of the workers in the United States similarly employed. The exclusion of aliens under this paragraph shall apply to special immigrants defined in section 1101 (a)(27)(A) of this title, (other than the parents, spouses, or children of United States citizens or of aliens lawfully admitted to the United States for permanent residence), to preference immigrant aliens described in sections $1153(a)(3)$ and $1153(a)(6)$ of this title, and to nonpreference immigrant aliens described in section $1153(\mathrm{a})(8)$ of this title . . ."

4 In re Bailey, 11 I. \& N. Dec. 466 (Bd. of Immigration App. 1966).

s. Id. at 471 .

7d. at 472.

"An indication that the Board was unaware of these changes is its footnote 2: "The 
sole authority for this major expansion of the commuter class was previous decisions of the Board. Although the Immigration and Naturalization Service amended its regulation, 8 C.F.R. $\S 211.1$ (b), to exclude commuters from the use of the greencard as a reentry document, the Service continued to permit aliens to come and go freely.

Paradoxically the only recognition of the commuter status in the Immigration and Naturalization regulations is the 1967 addition to 8 C.F.R. $\S 211.1(b)(1)$ which prohibits the use of a greencard as a reentry document "presented in lieu of an immigrant visa or a reentry permit" by an alien intending to work at the situs of a "labor dispute" involving a work stoppage or layoff of employees which has been certified by the Secretary of Labor ${ }^{72}$ Seemingly by its regulations, the Service is contending that the commuter status is valid except when the commuter is acting as a "strike breaker." Growing frustration with the continued availability of commuter and wetback labor to employers engaged in such disputes led to pressure for stringent inspection of dispute sites by both the Immigration and Naturalization Service and the Labor Department. As a result of such inspection, a grower and eleven commuter aliens challenged the regulation. ${ }^{73}$ Upholding the validity of the provision, the district court accepted the argument by the Immigration and Naturalization Service that the regulations were designed to restrict the use of the greencard as a document of entry for aliens living in a foreign country. ${ }^{74}$ The court refused to rule on the validity of the commuter system except to note that present law required an alien to obtain an immigrant visa or reentry permit for each entry into the United States. ${ }^{75}$

In 1968 another attack on the commuter system was launched in the courts based upon the failure of the Department of Justice to

Secretary of Labor has the power to prevent the admission of a commuter coming to employment in the United States which is harmful to American labor." Id. at 471. The Board predicated this footnote on the pre-1965 certification which cxcluded an alien only in the event of certification by the Labor Department. In re J-P-, 9 I. \& N. Dec. 466 (Bd. of Immigration App. 1966). After 1965 an affirmative certification was necessary to admit aliens entering to perform labor. See note 66 supra and accompanying text.

72 C.F.R. \& $211.1(\mathrm{~b})(1)(1968)$.

n Cermeno-Cerna v. Farrell, 291 F. Supp. 521 (D.C. Cal. 1968).

"Id. at 529.

${ }^{75}$ Id. 
implement the 1965 amendments to the Immigration laws. ${ }^{76}$ The government responded with a motion to dismiss in reliance upon $A F L-C I O$ v. Kennedy, ${ }^{77}$ asserting that farmworkers lacked the standing to challenge the failure of the Justice Department to comply with the 1965 amendments. The court has ordered that the motion will be regarded as one for a summary judgment. Briefs and affidavits having been submitted and the court is presently considering the matter on the merits. ${ }^{78}$

Aside from the pending court challenge, legislative and administrative changes in the commuter status have been proposed. One proposal recommends: (1) that all visas include a firm commitment to establish a bona fide residence in the United States; (2) creation of a new form of border crossing for aliens who wish to work in the United States and live in their own country, when their entrance will not adversely affect domestic workers; and (3) termination of the commuter status of present "greencards" holders. ${ }^{79}$

"Gooch v. Clark, No. 94500 (N.D. Cal., filed 'June 25, 1968). Plaintiffs seek to compel the Immigration and Naturalization Service and the Department of Justice to comply with 8 U.S.C. § II8I(b) (1964), as amended. (Supp. III, 1968) and 8 U.S.C. § I182(a)(14) (1964). Implementation of these provisions with respect to commuters would require that class of alien to possess a visa in good standing as a condition to entry requiring reapplication for a visa and recertification by the Labor Department at four-month intervals. The complaint also calls for the implementation of 8 U.S.C. \& 1101(a)(15)(H)(ii) (1964), a complementary means of identifying commuters as temporary workers who have not given up their foreign residence and reclassifying persons who meet that definition as non-immigrants. The change would give persons subjected to that reclassification the option to apply for a new visa and submit to the Labor Department's certification or to seek admission only as temporary labor.

"See notes 59-60 supra and accompanying text.

${ }^{7 x}$ As in Texas AFL-CIO v. Kennedy, the Department of Justice relies heavily on an affidavit from the Secretary of State dealing with the adverse foreign policy implications of a ruling terminating or restricting the commuter program. Since the Seeretary of State's authority in the arca of immigration is limited to the issuance and revocation of visas, 8 U.S.C. $\S 1104$ (1964), it appears that accession by the Department of Justice to foreign policy determinations as a rationalization for perpetuating the commuter status is unsupported by statute and in derogation of congressional intent.

"Richard M. Scammon and Stanley H. Ruttenberg, both members of the Select Commission on Western Hemisphere Immigration, made the following recommendations in a July 22, 1968 letter to President Johnson: "(1) As of a date certain, all visas issued for immigration into the United States be firmly understood to include a clear commitment by those immigrating to establish and maintain their bonafide residence within the United States .... (2) A new form of border crossing authorization be established, this authorization being designed for use by non-citizens who do not intend to become immigrants in the ordinary sense of the word, but who do wish to work in the United States and continue to reside in their own 'contiguous territory' country ... . Such a work permit 
An interim solution has been proposed by Senator Edward Kennedy and Congressman Michael Feighan. Their bill calls for recertification of all commuter aliens at six-month intervals to determine if their employment will adversely affect domestic workers as well as remedial legislation curtailing illegal entry. ${ }^{80}$

\section{Conclusion}

The efforts of Congress to protect domestic workers from the adverse impact of inexpensive foreign labor have been futile, at least with reference to the American Southwest. Abuses which Congress sought to suppress in its 1885 contract labor law thrive today in Mexican and American border towns. 1llegal entry increases largely unabated. Wholesale violation of limited visitation rights continues substantially unhindered by basic regulatory restraints. Commuter aliens, including many former illegal entrants expelled in the wetback roundups of the 1950's, displace American workers on the farms and in the cities and depress wages. Clear congressional enactments curtailing and controlling the commuter traffic atrophy from disuse.

Certainly additional legislative measures and further appropriations to law enforcement agencies should provide more effective antidotes to illegal entry and would tend to improve control over visitors and commuter aliens. However, such changes are futile unless the administrative agency charged with the implementation of the legislation is responsive to the intent of

should be issued under conditions which do not adversely affect standards of wages, hours, and working conditions in the United States and under circumstances in which resident workers are not available to fill the job in question. On issuance, such work permits should be reviewed from time to time to insure the conditions of their issuance are being observed ... . (3) Within a grace period, action should be taken to terminate the commuter status of present 'greencard' holders."

* Senate Bill No. 2790 was a proposal to amend 8 U.S.C. \$1182 (1964) to require a recertification of commuter aliens by the Labor Department at six-month intervals: "Any alien lawfully admitted for permanent residence whose principle, actual dwelling place is in a foreign country contiguous to the United States and is returning from a temporary stay in such foreign country to seek or continue employment in the United States shall be admitted into the United States only if the Secretary of Labor has determined and certified to the Attorney General within six months prior to the date of admission that the employment of such alien will not adversely affect the wages and working conditions of workers in the United States similarly employed, and if such certification has not been revoked on any ground. The provisions of this subsection shall be applicable to any aliens lawfully admitted for permanent residence, whether or not such aliens were so admitted prior to or on or after 
Congress. The failure of the Justice Department to modify its position regarding the commuter in the face of pertinent amendments to the Immigration laws, the failure to enact reasonable administrative controls over visitors, and the subordination of the interests of domestic labor to the concerns of farmers has the appearance of a substantial usurpation of the legislative function. Until society is willing to accord the poor and the minorities within the United States the economic and social benefits intended by the immigration laws, this country cannot expect these groups to respect the law and to willingly participate in the ordered society which such laws seek to create.

the date of enactment of this subsection." 113 CoNG. Rec. 18667 (daily ed. Dec. 14, 1967). The bill inherently ". . . provides for the revocation of a commuter alien's labor clearance, if he violates administrative regulations, such as a ban on strike breaking, prescribed by the Department of Labor and the Immigration Service to carry out the purpose of this bill." Id. at 18796 (remarks of Senator E. Kennedy). The bill was reintroduced jointly in the House and the Senate on March 26, 1969, by Senator Edward Kennedy and Representative Michael Feighan. Added to the measure this year is a section repealing the exemption from criminal sanction of employers who willfully and knowingly hire aliens present in the country illegally. The bill is co-sponsored by ten Senators and twenty-three Representatives. 115 Cong. REC. 3211 (daily ed. Mar. 26, 1969). 